\title{
China's High-tech Exports: Myth and Reality
}

\author{
By
}

\section{Yuqing Xing}

June 2011

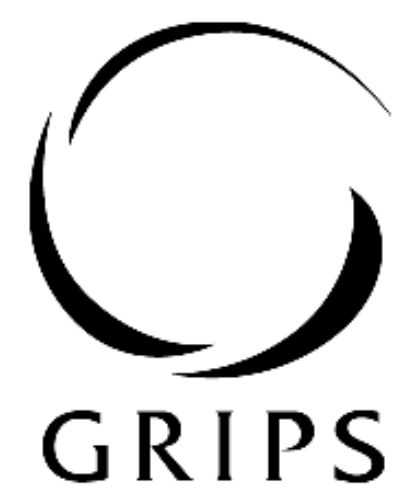

National Graduate institute FOR POLICY STUDIES

National Graduate Institute for Policy Studies 7-22-1 Roppongi, Minato-ku,

Tokyo, Japan 106-8677 


\title{
China's High-tech Exports: Myth and Reality
}

\author{
Yuqing Xing \\ National Graduate Institute for Policy Studies \\ 7-22-1 Roppongi Minato-ku, Tokyo \\ yuqing xing@grips.ac.jp
}

\begin{abstract}
China's leading position in high-tech exports is a myth created by outdated trade statistics, which are inconsistent with the trade based on global supply chains. Assembled high-tech products, made with imported key parts and components, accounted for $82 \%$ of China's high-tech exports. Current trade statistics mistakenly credit entire values of these assembled products to China, thus greatly inflate the export value. For instance, in 2009 China's export in the iPhone amounted US\$4.6 billion, of which only $3.6 \%$ was the value added by Chinese workers; its annual export in laptop PC valued at US\$52 billion, but assembly accounted for only $3 \%$ of the gross value. In addition, $83 \%$ of China's high-tech exports was attributed to foreign invested firms, in particular Taiwanese owned companies. Taiwan-IT companies have relocated $95 \%$ of their production/assembly capacity into and transferred mainland China to a top assembler of information and communication technology, such as laptop PCs, digital cameras and all i-products.
\end{abstract}

Key Words: China, high-tech, value added, iPhone 


\section{Introduction}

According to a report of the European Commission, China surpassed the US, EU-27 and Japan and emerged as the largest high-tech exporter in the world. In 2006, the global share of China's high-tech exports surged to $16.9 \%$, followed by the US' $16.8 \%$, EU-27's 15\% and Japan's 8\% (Meri, 2009). The statistics of the US Census Bureau showed that the US has consistently run trade deficit with China in advanced technology products since 2002. The deficit reached a record high of US\$94 billion in 2010 (US Census Bureau, 2011). The statistics by the Chinese government presented a similar story: China has turned into a high-tech export giant and its high-tech exports reached US\$377 billion, about 31\% of China's total exports in 2009 .

China was not a major player in the global market of high-tech products. Resource and labor intensive products have been dominating China's exports. In 1995, China accounted for a merely $2.1 \%$ of global high-tech exports. Its total exports in high-tech products were equivalent to only $8 \%$ of the US (Meri, 2009). With a 1.3 billion population, there is no surprise that China has been dominating the global market of labor intensive products. It is really a big surprise that China grew to be a top high-tech exporter within ten years. Given $1.6 \%$ of GDP R\&D expenditures, and 0.7\% R\&D intensity (Tong and Zhu, 2009), is China a real high-tech export champion, or is it just a myth?

In this paper, I analyzed the structure and the trade forms of China's high-tech exports as well as the ownerships of firms exporting high-tech products. The reality check suggests that the myth of China's leading position in high-tech exports has little to do with the technology advancement of indigenous companies. It is the outdated statistic method that bloated China's high-tech exports and artificially elevated China into the No.1 spot.

Of US\$377 billion high-tech exports, 82\% was processed/assembled high-tech products, mainly made of imported parts and components from industrialized economies, such as Germany, Japan, Korea, Taiwan and the US. China contributed very little intellectual properties to these assembled high-tech products. However, when these assembled high-tech products are shipped abroad, the Chinese Customs 
classifies them as high-tech exports, regardless whether China's contribution is labor or technology; the entire value of these assembled high-tech products is credited to China, regardless whether most of key parts and components are imported or domestically made. Therefore, current trade statistics are misleading and greatly inflated China's exports in high-tech products and created a myth. If the value added approach was employed to record trade flows, the value of the high-tech exports would shrink significantly.

The series of i-products designed by Apple are a typical example. All iPods, iPhones and iPads are exclusively assembled in China. The role of Chinese workers in the global supply chain of i-products is simply to screw all parts together and make ready-to-use i-products and ship them to the world market. When these ready-to-use i-products leave Chinese ports, they are classified as high-tech exports and all value added embedded are fully credited to China. A false trade pattern was then created by these trade statistics: China - a developing country exports high-tech products while developed countries such as Japan and the US import high-tech products invented by themselves. For instance, in 2009 China exported 25.7million iphone--an iconic American product, valued at US\$4.6 billion. The decomposition long the value chain of the iPhone reveals that, a merely US\$167 million about 3.6\%, was the actual value added by Chinese workers; the rest was a transfer from Germany, Japan, Korea and the US, the major suppliers of the iPhone parts and components (Xing and Detert, 2010).

In addition, the analysis on the ownership of the firms exporting high-tech products shows that, foreign invested firms accounted for $83 \%$ of China's high-tech exports; in particular wholly foreign owned firms dominated the sector and made up 68\%. Therefore, it is foreign direct investment (FDI) and outsourcing activities of multinational enterprises (MNE) that transformed China into a world high-tech assembling factory. Taiwan-IT companies, the leading global maker of information and communication technology (ICT), performed the most critical role in the transition. They have relocated $95 \%$ of their assembling capacities in ICT into mainland China (Market Intelligence Center, 2010). The abundant labor resource in mainland China and the direct investment from Taiwan jointly made China a top maker of various ICT products, such as laptop PC, digital camera and all trendy 
i-products. This explains why ICT accounted for $75 \%$ of China's high-tech exports.

\section{Reported Growth of China's High-tech Exports}

In China's official statistics in high-tech trade, high-tech products consist of nine product categories: computers and telecommunications, life science technologies, electronics, computer-integrated manufacturing, aerospace, optical-electronics, biotechnology, materials, and others. The classification is jointly published by China's Ministry of Science and Technology and the Ministry of Commerce. It is basically comparable with that of the US for exports and imports of advanced technology products.

Figure 1

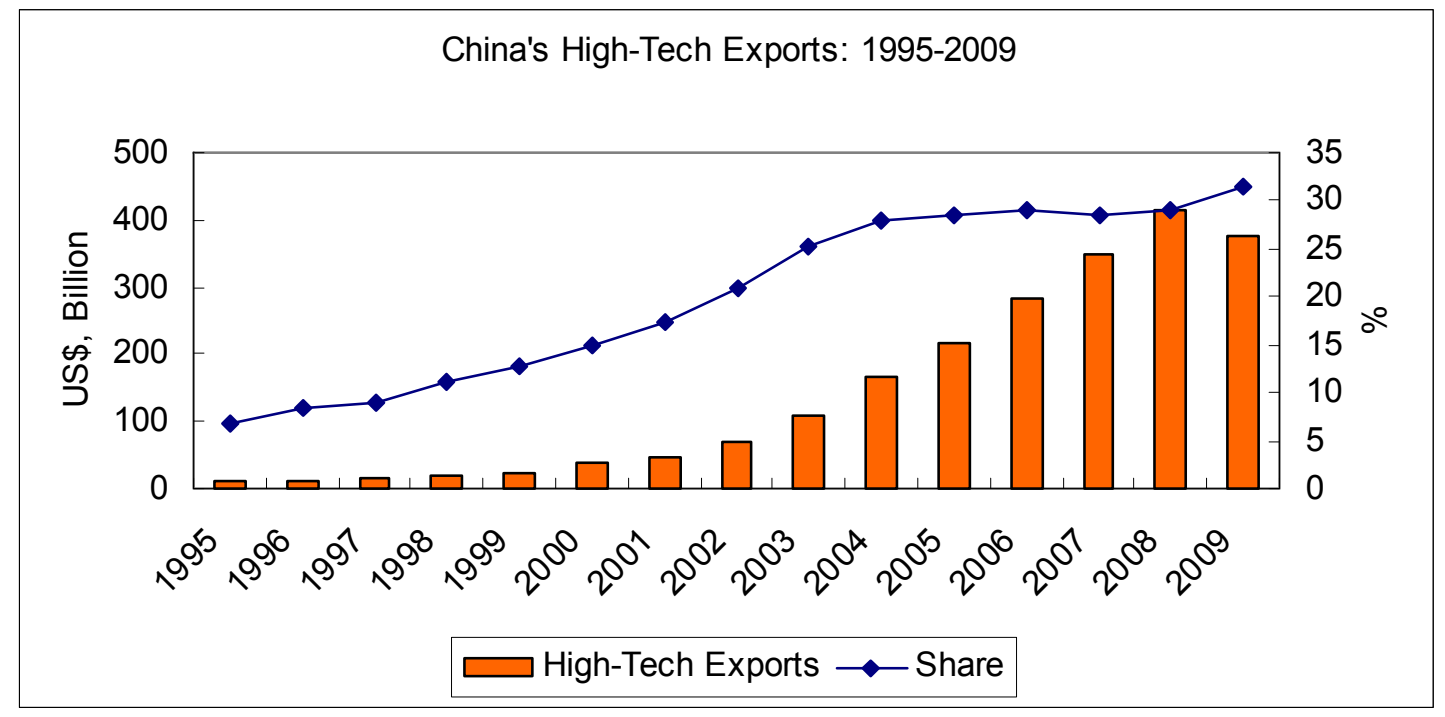

Source: Statistics on Science and Technology, the Chinese Ministry of Science and Technology.

Figure 1 shows the trend of China's high-tech exports from 1995 to 2009. In 1995, the value of high-tech exports was moderate and amounted to US\$10.1 billion, about $6.8 \%$ of total exports. From 1995 to 2009, high-tech exports grew 30\% annually, much faster than the growth of overall exports. In 2009, high-tech exports rose to US\$376.9 billion, accounting for 31.4\% of total exports. Before 2004, China constantly had a trade deficit in high-tech products. The rapid expansion of high-tech exports turned the trade deficit to surplus. In 2009, trade surplus in high-tech products surged to US $\$ 67$ billion, equivalent to a $34 \%$ of total trade surplus. 
Table 1 China's High-tech Trade by Technologies, 2009

\begin{tabular}{|l|c|c|c|c|c|}
\hline \multicolumn{1}{|c|}{ Technologies } & \multicolumn{2}{|c|}{ Exports } & \multicolumn{2}{c|}{ Imports } & $\begin{array}{c}\text { Trade } \\
\text { Balance }\end{array}$ \\
\hline & $\begin{array}{c}\text { Value } \\
\text { (US\$ } \\
\text { billion) }\end{array}$ & $\begin{array}{c}\text { Share } \\
\text { (\%) }\end{array}$ & $\begin{array}{c}\text { Value } \\
\text { (US\$ billion) }\end{array}$ & $\begin{array}{c}\text { Share } \\
\text { (\%) }\end{array}$ & $\begin{array}{c}\text { Value } \\
\text { (US\$ } \\
\text { billion) }\end{array}$ \\
\hline $\begin{array}{l}\text { Computer and } \\
\text { Telecommunications }\end{array}$ & 282.5 & 74.9 & 73.6 & 23.7 & 208.9 \\
\hline $\begin{array}{l}\text { Life Science } \\
\text { technologies }\end{array}$ & 11.1 & 2.9 & 9.5 & 3.1 & 1.6 \\
\hline Electronics & 51.1 & 13.6 & 148.5 & 47.9 & -97.4 \\
\hline $\begin{array}{l}\text { Computer-integrated } \\
\text { manufacturing }\end{array}$ & 5.1 & 1.4 & 19.7 & 6.4 & -14.6 \\
\hline Aerospace & 2.7 & 0.7 & 14.0 & 4.5 & -11.4 \\
\hline Optoelectronics & 20.9 & 5.6 & 38.5 & 12.4 & -17.6 \\
\hline Biotechnology & 0.3 & 0.1 & 0.4 & 0.1 & -0.1 \\
\hline Materials & 3.0 & 0.8 & 5.1 & 1.6 & -2.1 \\
\hline Others & 0.4 & 0.1 & 0.6 & 0.2 & -0.2 \\
\hline Total & 376.9 & 100 & 309.9 & 100 & 67.1 \\
\hline
\end{tabular}

Sources: Statistics on Science and Technology, the Chinese Ministry of Sciences and Technology.

Table 1 shows the structure of China's high-tech exports in 2009. Computer and telecommunication equipment and electronics comprise a majority of high-tech exports. The exports in computer and telecommunication totaled US\$283 billion, about $75 \%$ of total high-tech exports; electronics ranked second with US\$51 billion (about 14\%). The combined export in the two categories accounted for almost $90 \%$ of the total high-tech exports. It is worthy to mention that, trade in computer and telecommunication generated US\$209 billion surplus while there is a US\$ 97 billion deficit in electronics. Many imported parts and components, used as intermediate inputs, are classified as electronics. This is one of the reasons causing the deficit in the trade of electronics. Global supply chains in ICT are distributed across countries and China is integrated into the low value added portion of the supply chains-assembling. The large share and the surplus of computer and telecommunication are consistent with the fact that, China is positioned at the last stage of the ICT production chain-assembly and current trade statistics ascribe the entire value of an assembled high-tech product to the country shipping the product abroad. 


\section{High-tech or Assembled High-tech Products?}

The Chinese Customs classifies trade into two major categories: processing and ordinary. Trading forms of high-tech exports can help in the understanding of the nature of China's high-tech export myth. Processing trade is a unique form of China's foreign trade and represents 40\% of China's exports (Xing, 2011). Processing exports are produced with imported materials, parts, components, and even packaging materials. These intermediate inputs are either purchased by companies located in China, or supplied by foreign firms without financial payment.

Figure 2

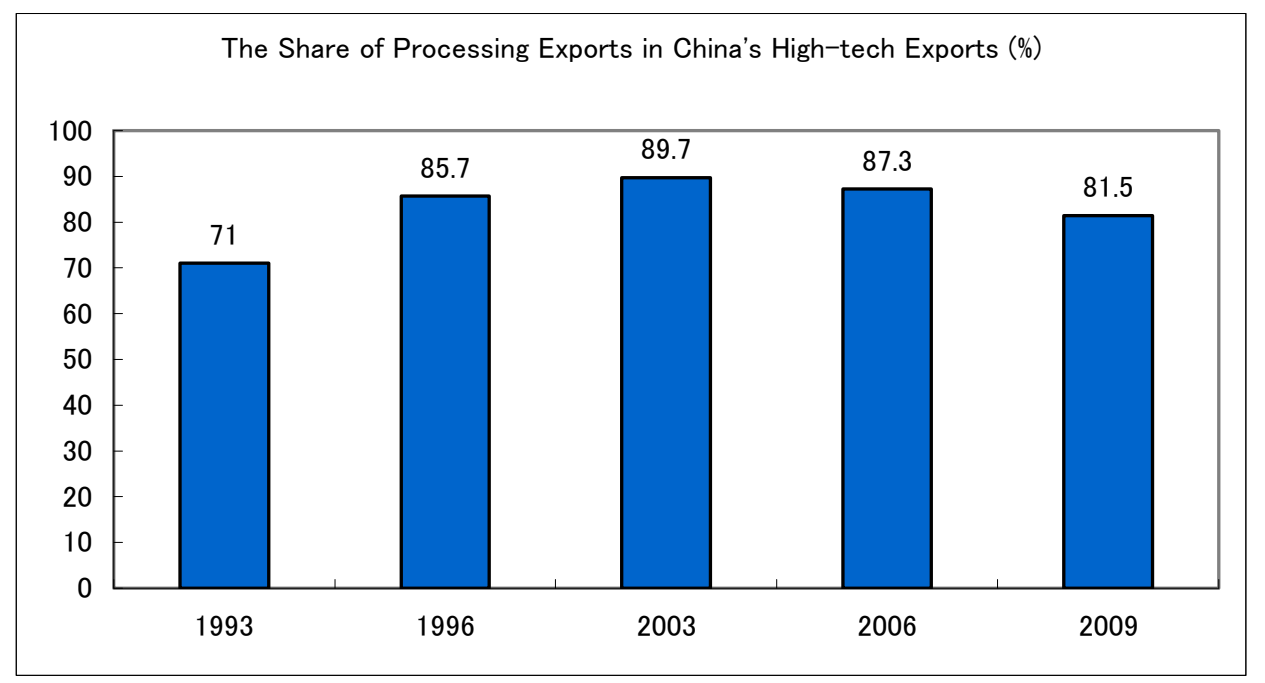

Source: Statistics on Science and Technology, the Chinese Ministry of Science and Technology.

Due to the lack of technology advantages, processing trade has been the major form of high-tech exports since the early 1990s (Figure 2). In 1993, China exported US\$4 billion high-tech products, of which processing exports accounted for $71 \%$. As more and more foreign firms took advantage of China's cheap labor by relocating labor intensive segments of production chains to China and utilizing China as an export platform, the share of processing exports in high-tech products grew dramatically and jumped to $90 \%$ in 2003 . The increase in processing trade implies that China's high-tech exports actually became more labor intensive rather than capital/technology intensive after ten years of rapid expansion. The share of processing exports declined slightly to $82 \%$ in 2009 , but remained dominant. Since key parts and components in assembled high-tech products are imported and screwing these intermediate inputs into finished products requires only low skill workers, the 
contribution of Chinese workers to these products is not advanced technology, but labor. Hence, the technological sophistication of these products cannot be used to measure the technology advancement of China. High-tech products made of imported key parts and components should be called "assembled high-tech" and excluded from the high-tech classification.

An interesting question is to what extent current trade statistics inflate China's high-tech export value. In other words, how much value added of high-tech exports could be attributed to Chinese workers? Both the iPhone and laptop PC belong to the category of computers and information technology and represent major items in high-tech exports. Here, I use the iPhone and laptop PC as examples to illustrate how much China's contribution is.

Table 2. China's Exports in the iPhone and Laptop PC, 2009

\begin{tabular}{cccccc}
\hline & $\begin{array}{c}\text { Volume } \\
\text { (million) }\end{array}$ & Unit & $\begin{array}{c}\text { Export Value } \\
\text { (million US\$) }\end{array}$ & $\begin{array}{c}\text { Unit Value } \\
\text { added by } \\
\text { China* }\end{array}$ & $\begin{array}{c}\text { Export by } \\
\text { value added } \\
\text { (million US\$) }\end{array}$ \\
\hline The iPhone & 25.7 & $\$ 179$ & 4,600 & $\$ 6.5$ & 167 \\
Laptop PC & 108.5 & $\$ 484$ & 52,514 & $\$ 14.5$ & 1,573 \\
\hline
\end{tabular}

Sources: Xing and Detert (2010), Dedrick, Kraemer and Linden(2010), Information Industry Yearbook 2010 (MIC) and the author's estimations.

Note: * assembling costs only

According to Xing and Detert(2010), in 2009 China exported 25.7 million 3G iPhones at US\$179 per unit. The total iPhone export valued at US\$4.6 billion, about $1.2 \%$ of its high-tech exports. Since the value added by China is only US\$6.5 per iPhone and the rest is attributed to imported parts and components from Germany, Japan, Korea and the US, in terms of value added China's iPhone export was only US\$ 167 million, about $3.6 \%$ of the US $\$ 4.6$ billion. Classifying the iPhone as China's high-tech export is misleading and significantly inflates its high-tech export value.

China is the No.1 laptop PC maker in the world. In 2009, it exported 108.5 million laptop PCs with an average selling price US\$484 per unit (MIC, 2010). The total laptop PC exports amounted US\$52.5 billion, about 14\% of total high-tech exports. 
Dedrick, Kraemer and Linden (2009) estimated that assembly represents 3\% of the entire manufacturing cost of a laptop PC. Using this estimate as a reference, the value added per laptop PC by Chinese workers would be US\$14.5 and China's laptop PC export in terms of the value added would be US\$1.6 billion, much lower than indicated by conventional trade statistics.

The iPhone and laptop PC together made up 15\% of China's high-tech exports. It is not appropriate to use the low valued added in these two products to make a general conclusion for all high-tech exports. On the other hand, given that $75 \%$ of high-tech exports belongs to the category of computer and communication technology and $82 \%$ is assembled with imported parts and components, there is no doubt that current trade statistics greatly exaggerate the value of high-tech exports. It is misleading to claim that China became a global leader in high-tech trade. Trade statistics failed to identify country origins of key technology contents and erroneously depicted China as a No.1 high-tech exporter. To accurately describe China's position in global high-tech trade, the value added approach should be employed and the detailed country distribution of value chains are essential. Moreover, assembling parts and components into finished products only requires low skill labor and has no difference with making shoes or toys. Even if the value added approach was adopted, whether assembling high-tech products should be considered as an advanced technology remained a question for debates.

\section{Who Produces China's High-tech Exports?}

What are the major reasons for such a dramatic surge in high-tech exports from US\$10 billion to \$US377 billion in less than two decades? FDI and the extension of production network of MNEs from Japan, Korea, Taiwan, Singapore and other economies into China, is the answer. The advancement in production technology and transportation has greatly facilitated the spread of MNE production chains across borders. Conventional specialization of products has been replaced by the specialization on parts, components as well as production procedures. In computer, telecommunication and electronics industries, specialization on parts and production procedures and global production networks have been well developed by MNEs, especially MNEs of Japan, Korea and Taiwan. 
China's openness to FDI and its rich endowment in labor constantly attract MNEs to relocate their product capacities, outsource labor intensive components to China and integrate China into their global production networks, thus boosting the production of high-tech goods. On the other hand, the production technology, distribution networks and brand names of MNEs function as vehicles for made-in-China products to access the global market.

Figure 3. Foreign invested firms' contribution to China's high-tech exports (\%)

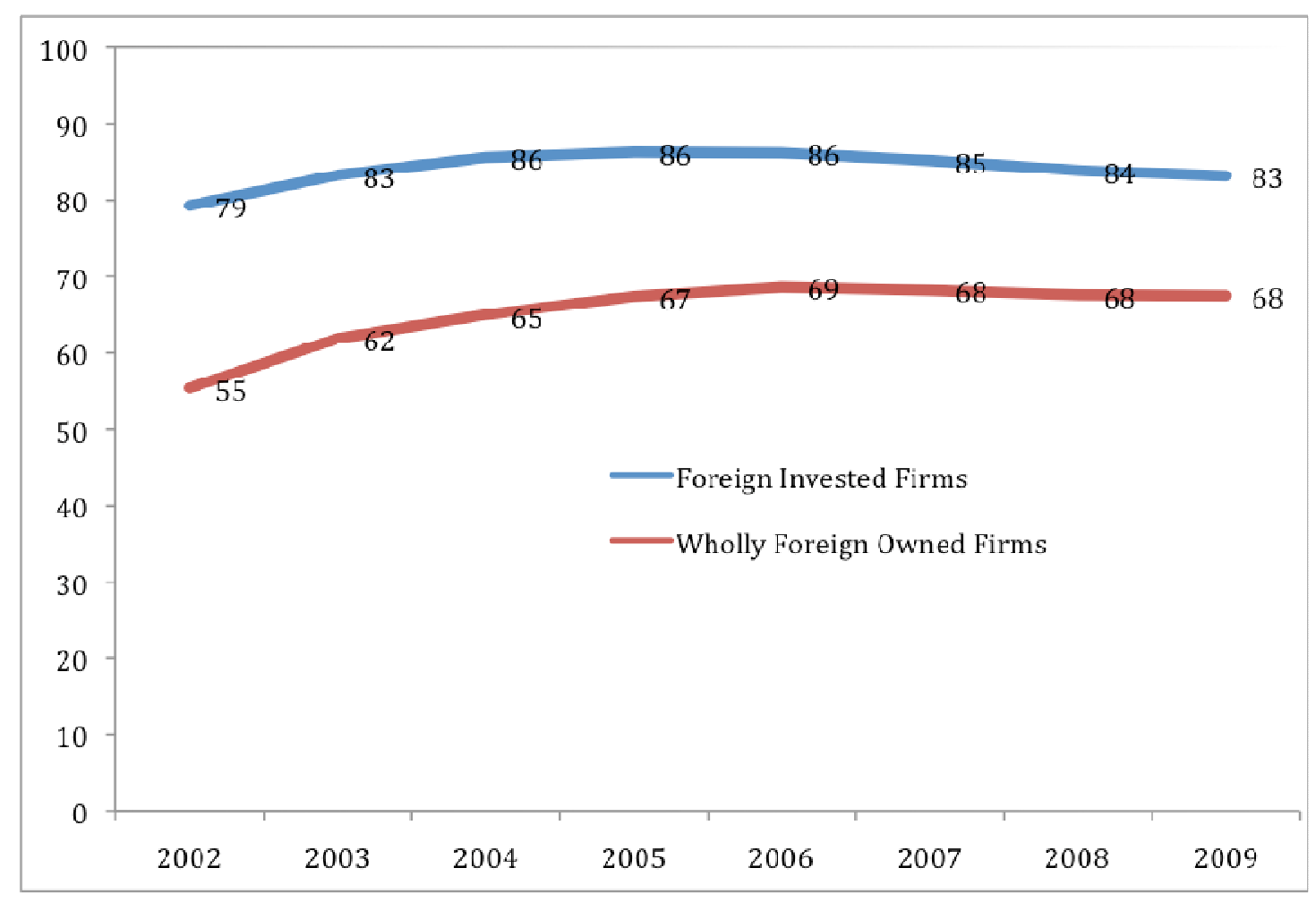

Sources: Statistics on Science and Technology, various issues, The Chinese Ministry of Science and Technology.

It is well known that foreign invested firms have been driving the rapid growth and producing more than half of China's exports. In high-tech products, foreign invested firms have been playing an even more crucial role, dominating China's high-tech exports. Figure 3 shows the contribution of foreign invested firms to high-tech exports. In 2002, foreign invested firms produced $79 \%$ of high-tech exports while wholly foreign owned firms $55 \%$. Since then, the dominance of foreign invested firms has been further strengthened as more and more FDI flew into China. In 2004, the share of foreign invested firms grew to $86 \%$; in 2006 the share of wholly foreign owned 
increased to $69 \%$. The dominance of foreign invested firms in high-tech exports changed very little and their share remained as high as $83 \%$ in 2009 .

High-tech exports of the Sino-foreign joint-ventures may represent the technology advancement of Chinese partners of these ventures to a certain extent. However, the technology and production know-how used for producing exports of wholly foreign owned firms belong to foreign investors and have nothing to do with Chinese indigenous firms. The spillover effects might lead to technology progress of local firms. It is ambiguous to what extent they benefited from the presence of foreign invested firms in high-tech sector. The share of indigenous firms in high-tech exports had been small. In 2009, it slipped to 17\%, 4 percentage points lower than in 1995 . The relatively small share implies that, the spillover effects are very limited, if there is any, and indigenous firms are far from being a real competitor to multinational firms in industrialized countries.

Among all foreign investors, Taiwan-IT companies made a major contribution to the rapid expansion of China's high-tech exports in information and communication technology industry. As indicated in Table 1, computers, telecommunication and electronics products represent the largest group in high-tech exports. Close to $90 \%$ of high-tech exports belongs to this category. It is the relocation of production facilities from Taiwan that helped China emerge as a leading IT exporter in the world. The relocation simply transplanted the success of Taiwan's semiconductors to mainland China.

Table 3 Stylized Facts of Taiwanese-owned IT Companies, 2007

\begin{tabular}{lcccccc}
\hline & $\begin{array}{c}\text { Laptop } \\
\text { PC }\end{array}$ & $\begin{array}{c}\text { Desktop } \\
\text { PC }\end{array}$ & Motherboard & $\begin{array}{c}\text { LCD } \\
\text { monitor } \\
\text { for PC }\end{array}$ & Servers & $\begin{array}{c}\text { Digital } \\
\text { Camera }\end{array}$ \\
\hline $\begin{array}{l}\text { Rank in Market } \\
\text { share }\end{array}$ & 1 & 2 & 1 & 1 & 2 & 2 \\
$\begin{array}{l}\text { Annual Output } \\
(1,000 \text { unit) }\end{array}$ & 90,165 & 46,055 & 149,097 & 117,539 & 2,950 & 49,896 \\
$\begin{array}{l}\text { Global Market } \\
\text { Share (\%) }\end{array}$ & 92.8 & 32.6 & 97.2 & 70.2 & 35.2 & 42.2 \\
*Exports as (\%) & 91.5 & 82.8 & 73.7 & 80.5 & 89.4 & 95 \\
of output & & & & & & \\
\hline
\end{tabular}

*: Exports consist of all sales outside of Mainland China and Taiwan.

Sources: Information Industry Yearbook 2008 (MIC). 
Since 1980, Taiwan has developed technology and production capacities in semiconductor and information technology industry. Taiwanese companies have become the largest original equipment manufacturers (OEM) and original design manufacturers (ODM) for leading international IT firms such as IBM, DELL, Intel, SONY, etc. OEM and ODM are the major forms of production fragmentation in information and telecommunication industries. As production technologies in IT industries are gradually maturing and production processes are being standardized, IT products become commodities rather than high-tech goods. It is easy to divide production into segments and locate in different countries.

In terms of global market shares, in 2007, Taiwanese companies ranked number one in laptop computer with more than 90 million units, LCD monitor for PC with 117.5 million units, and motherboards with 149 million units; they are also ranked number two in desktop PC, and servers, and digital cameras (Table 3). Most of these IT products are sold in markets outside of Taiwan and mainland China. For instance, $95 \%$ of digital cameras, $92 \%$ of laptops and $89 \%$ of servers are exported to overseas market.

Table 4 Shares of Major IT Products by Taiwan and Made in Mainland China (\%)

\begin{tabular}{ccccccc}
\hline & Laptop PC & $\begin{array}{c}\text { Desk Top } \\
\text { PC }\end{array}$ & Motherboard & Server & $\begin{array}{c}\text { LCD monitor } \\
\text { for PC }\end{array}$ & $\begin{array}{c}\text { digital } \\
\text { camera }\end{array}$ \\
\hline 2003 & 54.3 & 51.7 & 73.9 & 21.3 & 79.1 & 89.2 \\
2004 & 77.8 & 54.1 & 86.2 & 25 & 84.6 & 98 \\
2005 & 92.8 & 57.5 & 91.6 & 42.2 & 88.7 & 98.5 \\
2006 & 96.9 & 63.9 & 94 & 53.4 & 90.6 & 99 \\
2007 & 97.8 & 71.7 & 96.4 & 57.5 & 91.5 & 98 \\
\hline
\end{tabular}

Sources: Information Industry Yearbook, various issues.

To strengthen their competitiveness and to lower production costs, Taiwanese companies have gradually relocated most of their production capacities to mainland China. Relocating the production of these products into mainland China immediately increased the China's output in IT products and created an ICT growth myth. Specifically, by $2007,98 \%$ of digital cameras made by Taiwan were produced in its 
mainland China factories; the same could be said of $97.8 \%$ of laptop computers, $57 \%$ of servers and close to $92 \%$ of LCD monitors for PC (table 4). All iPhones and iPads sold in the global market are assembled by Foxconn, a Taiwanese owned firm located China. By 2009, Taiwan-IT companies relocated $95 \%$ of their assembling capacities in ICT into mainland China (Market Intelligence Center, 2010). Therefore, it is the combination of FDI from Taiwan and abundant labor in mainland China that turned China into the number one of global IT assembler.

\section{Concluding Remarks: Myth and Reality}

In sum, the myth of China's high-tech exports is created by outdated trade statistics and incorrect product classifications. The prevailing trade statistics are inconsistent with the trade based on global supply chains and mistakenly credit entire values of assembled high-tech products to China, thus greatly inflate the corresponding export value. China's real contribution to $82 \%$ of reported high-tech exports is labor and not technology. High-tech products, mainly made of imported parts and components, should be called "Assembled High-tech". To accurately measure high-tech exports, value added approach should be employed and detailed analysis on the value chains distributions across countries are indispensable. If assembly is the only source of the value added by Chinese workers, in terms of technological contribution these assembled high-tech exports are indifferent with labor intensive products, such as shoes and toys; they should be excluded from the high-tech classification.

MNEs, in particular Taiwan-IT firms in China, have performed an important role in the rapid expansion of high-tech exports. The trend of production fragmentation and outsourcing activities of MNEs in information and communication technology has benefited China significantly, because of its huge labor endowment. The small share of indigenous firms in high-tech exports implies that China has yet to become a real competitor of the US, EU and Japan. That China is the No. 1 high-tech exporter is a myth rather than a reality. 


\section{References}

Dedrick, J., Kraemer, K.L., Linden, G. (2010) "Who profits from innovation in global value chains? A study of the iPod and notebook PCs." Industrial and Corporate Change 19(1), 81-116.

Market Intelligence Center (MIC), Information Industry Yearbook 2010, Taiwan: Institute for Information Industry, Taiwan.

Meri, T. (2009), "China passes the EU in high-tech exports," Science and Technology, Eurostat Statistics in focus.

Tong, S and Zhu, J. (2009), "China's Rapidly Growing Enterprise-led Innovation System, No. 461, EAI Background Brief.

US. Census Bureau (2011), "U.S. Trade with China in Advanced Technology Products,"

http://www.census.gov/foreign-trade/statistics/product/atp/2010/12/ctryatp/atp5700.ht $\underline{m}$

Xing, Y. (2011), "Processing Trade, Exchange Rates and China's Bilateral Trade Balances," ADBI working paper No. 270.

Xing, Y and N. Detert (2010), "How the iPhone widens the US trade deficit with the PRC," ADBI working paper No. 257, Tokyo: Asian Development Bank Institute. 